Review

\title{
Impact of Grafting on Watermelon Fruit Maturity and Quality
}

\author{
Pinki Devi ${ }^{1}$ (), Penelope Perkins-Veazie ${ }^{2}$ and Carol Miles ${ }^{1, *}$ \\ 1 Northwestern Washington Research \& Extension Center, Department of Horticulture, \\ Washington State University, Mount Vernon, WA 98273, USA; pinki.devi@wsu.edu \\ 2 Department of Horticulture, Plants for Human Health Institute, North Carolina State University, Kannapolis, \\ NC 28081, USA; penelope_perkins@ncsu.edu \\ * Correspondence: milesc@wsu.edu
}

Received: 19 November 2020; Accepted: 4 December 2020; Published: 8 December 2020

\begin{abstract}
Watermelon (Citrullus lanatus) grafting has emerged as a promising biological management approach aimed at increasing tolerance to abiotic stressors, such as unfavorable environmental conditions. These conditions include environments that are too cold, wet, or dry, have soil nutrient deficiency or toxicity and soil or irrigation water salinity. Studies to date indicate that fruit yield and quality may be positively or negatively affected depending on rootstock-scion combination and growing environment. Growers need information regarding the general effect of rootstocks, as well as specific scion-rootstock interactions on fruit maturity and quality so they can select combinations best suited for their environment. This review summarizes the literature on watermelon grafting with a focus on abiotic stress tolerance and fruit maturity and quality with specific reference to hollow heart and hard seed formation, flesh firmness, total soluble solids, and lycopene content.
\end{abstract}

Keywords: flesh firmness; flowering; harvest time; lycopene; rootstock-scion combination; total soluble solids

\section{Introduction}

Grafting watermelon (Citrullus lanatus) onto disease resistant rootstock can minimize the problems associated with soil-borne diseases, such as Fusarium wilt (caused by Fusarium oxysporum f. sp. niveum) and Verticillium wilt (caused by Verticillium dahliae), as well as infection by root nematodes (Meloidogyne incognita) [1,2]. In addition, grafting can provide watermelon with tolerance against abiotic stressors, including temperature extremes, soil salinity, and nutrient deficiency or toxicity [3-6]. For example, grafting can be used to advance the planting date of watermelon due to tolerance of cool soil $[1,7]$. The root architecture of selected rootstocks enables better performance against abiotic stress factors through improved uptake of water and macro/micronutrients [5,8-11]. These recent advances in the understanding of rootstock-mediated effects on scion performance have broadened the application of grafting for the cultivation of watermelon under adverse environments.

To take advantage of grafting, growers need information regarding fruit maturity and quality (flesh firmness, total soluble solids (TSSs), lycopene content, etc.) in response to rootstock-scion combinations under various environmental conditions. For a non-climacteric fruit like watermelon, fruit maturity at harvest is especially important. The effect of rootstocks, scion-rootstock interaction, and environmental conditions on the timing of fruit maturity is needed to ensure fruit quality from grafted watermelon is optimized. Studies to date indicate that depending on rootstock-scion combination, fruit yield, and quality attributes may be either positively or negatively affected by grafting. However, most literature relies on the assumption of synchronous ripening in grafted and nongrafted plants, potentially leading to the confounding reports for fruit maturity and fruit quality 
resulting from grafting. Therefore, determining an appropriate harvest time for grafted watermelon is essential to maintain yield and quality stability.

\section{Factors Affecting Time of Harvest}

Harvest time may be affected when time of flowering is affected. Time of flowering may be impacted due to modification of hormonal signaling in response to the rootstock-scion combination of a grafted watermelon) [1,12-15]. Sakata et al. [14] reported that watermelon grafted onto bottle gourd (Lagenaria siceraria) has early formation of female flowers. In contrast, Davis et al. [1] reported a delay in flowering of up to 1 week with watermelon grafted on bottle gourd, resulting in an equal delay in fruit maturity. Delayed flowering was also observed for watermelon cv. Fujihikari, grafted onto pumpkin (Cucurbita maxima), wax gourd (Benincasa hispida), and interspecific hybrid squash rootstocks (C. maxima $\times$ C. moschata) compared to nongrafted treatments in the greenhouse [16]. Compared to nongrafted plants, female flowering of cv. Secretariat was delayed by 13 days and by 7 days when grafted onto bottle gourd cv. Round and interspecific hybrid squash cv., respectively, but there were no differences in days to harvest or fruit maturity [17]. The differences in flower initiation response could be due to hormonal signaling, combined with environmental effects that occur during graft union formation. For example, cytokinin is higher in grafted plants than nongrafted plants and could potentially have an effect on flowering time [11,18].

Because grafting may affect flowering and the harvest date, harvesting fruit from grafted and nongrafted plants concurrently may be the cause of conflicting results regarding fruit quality [1]. Most studies have assumed concurrent ripening of fruit from grafted and nongrafted plants, and fruit has been harvested at the same time for all treatments. Further, most studies reporting the effect of different rootstocks on fruit quality have not reported fruit maturity indices at harvest, such as senescence of leaflet and tendril attached to the fruit pedicel, skin color development, or ground spot formation. Yet for non-climacteric fruit, such as watermelon, fruit maturity at harvest has a major impact on fruit quality characteristics [18,19]. Kroggel and Kubota [20] reported that grafted fruit should be harvested 5 days after the leaflet and tendril are completely dry. Devi et al. [21] found that fruit quality of grafted watermelon was optimized with a 7-day delayed harvest from when those indicators of fruit physiological maturity occurred. The increase in time to harvest is likely due to the increased vigor of the rootstock, including increased water, oxygen, and mineral uptake [22,23]. Thus, reports of reduced fruit quality of grafted watermelon may not be an attribute imparted from grafting, rather reduced quality may be a factor of improper (early) harvest timing [24].

\section{Effect of Grafting on Fruit Quality}

Regardless of the advantages of grafting, there are still concerns that grafting could potentially reduce watermelon fruit quality below United States Department of Agriculture market standards of $10 \%$ soluble solid content (SSC) and $13 \mathrm{~N}$ flesh firmness [25]. Quality of grafted fruit must be equal to or better than that of nongrafted watermelon to ensure market acceptability $[3,26,27]$. Grafting can enhance fruit quality of watermelon by increasing the synthesis of endogenous hormones and the acquisition and transport of mineral nutrients $[2,28]$ and also by altering secondary metabolites [2,29]. While fruit quality attributes from grafted plants have generally been found to be consistent with or slightly improved compared to nongrafted plants, results appear to be specific to rootstock-scion combinations under particular environmental conditions [30-35]. These effects contribute to contradictory reports of the impact of grafting on fruit quality [1]. Overall, most rootstocks, except bottle gourd, have been reported to increase watermelon fruit flesh firmness, total soluble solids (TSSs), and lycopene content compared to nongrafted fruit [26,36-39].

\subsection{Hollow Heart and Hard Seed Formation}

Hollow heart (placental detachment from the rest of the flesh) (Figure 1A) and hard seed formation (Figure 1B) are morphological abnormalities sometimes associated with grafted triploid watermelon 
and may reflect rootstock-scion incompatibility and/or adverse environmental conditions or cultural practices $[1,16,22]$. Seedless watermelon varieties are known to be more susceptible to hollow heart than seeded varieties, and currently, $95 \%$ of US watermelon production uses seedless cultivars [40,41]. Although there is no definitive cause, multiple factors, such as genetics, pollination, pollen viability, flowering time, decreased fruit tissue firmness, and environmental stressors, such as cold night temperatures, can cause this physiological disorder, especially in seedless watermelon $[40,42,43]$. A challenging problem with hollow heart disorder is that it is difficult to predict when it will occur. Johnson [40] reported that the primary cause of hollow heart is inadequate pollination. Triploid watermelon does not produce sufficient viable pollen and requires diploid (seeded) pollen sources [44]. When the distance from triploid plants to pollenizer plants increases, the incidence of hollow heart increases. Triploid plants located $1.5 \mathrm{~m}$ away from a pollenizer plant showed a hollow heart incidence of $56 \%$, and plants located $2.4 \mathrm{~m}$ away from a pollenizer had a $74 \%$ incidence [40]. Prolonged periods of hot day-time temperatures also lower bee activity and pollination rates. Furthermore, pollen viability and rates of pollination are reduced by cold weather and prolonged periods of hot day-time temperature.

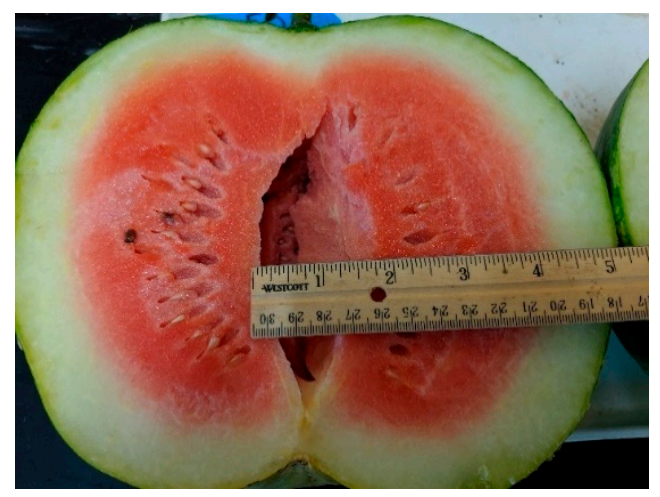

(A)

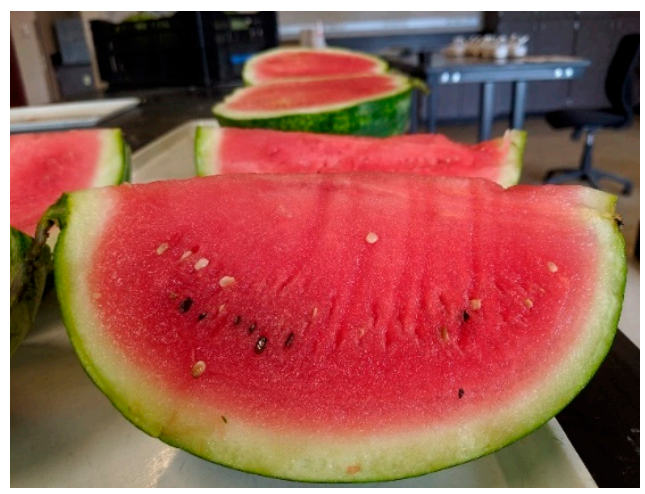

(B)

Figure 1. Hollow heart (A) and black seed formation (B) in grafted triploid watermelon.

Hollow heart is less likely to occur when fruit set is later in the season [43]. Grafting watermelon onto interspecific hybrid rootstock has been shown to increase fruit tissue firmness and may decrease the susceptibility of hollow heart formation in triploid watermelon [41]. For example, in North Carolina, where day/night temperature was $25^{\circ} \mathrm{C} / 15^{\circ} \mathrm{C}$, hollow heart incidence was reduced by $25-30 \%$ in fruit of triploid cv. Liberty grafted onto interspecific squash hybrid rootstock cvs. Carnivor and Kazako, compared to nongrafted fruit [45]. In contrast, Devi et al. [17] reported that in northwest Washington $\left(16^{\circ} \mathrm{C} / 10.5^{\circ} \mathrm{C}\right.$ mean day/night temperature during the growing season), hollow heart formation was high (13-25 mm cracking, non-marketable) for cv. Secretariat nongrafted, as well as that grafted onto interspecific hybrid squash cvs. Tetsukabuto and Super Shintosa, bottle gourd cv. Pelop, and wax gourd cv. Round.

Immature white seed is commonly found in triploid watermelon, and under certain stress/ environmental conditions, some seed coats may become hard and black and look like a mature seed but are empty inside [44,46] Unfavorable conditions, such as moisture extremes (drought, flood), fertilizer imbalance, or temperature extremes may cause the formation of hard seeds [44]. There is concern among growers that grafting may adversely increase the formation of hard seeds in triploid watermelon. Devi at al. [17] found six hard seeds per fruit on average for both grafted and nongrafted watermelon fruit in northwest Washington. At this study site, night temperature was $10.5{ }^{\circ} \mathrm{C}$ on average, which could account for the high incidence of hollow heart and formation of hard seed. 


\subsection{Flesh Firmness}

Increased flesh firmness of grafted watermelon fruit has been shown in many studies [17,21,26,31,32,47-49], while no change was reported by some studies [50-52] Interspecific squash hybrid rootstocks appear to increase watermelon flesh firmness most consistently in both diploid and triploid scions [26,38,53]. Liu et al. [54] reported no difference in firmness when diploid watermelons were grafted onto five different L. siceraria and Cucurbita ficifolia rootstocks. In contrast, Yamasaki et al. [16] reported a significant increase in firmness when diploid watermelon cv. Fujihikari was grafted onto C. maxima $\times$ C. moschata hybrid rootstock than onto L. siceraria. Bruton et al. [26] reported increased firmness in both diploid and triploid watermelon when grafted onto C. ficifolia and C. maxima $\times C$. moschata hybrid rootstocks, but $L$. ciceraria rootstock produced lower or more varied fruit firmness. Similarly, triploid watermelon cv. Secretariat grafted onto C. maxima $\times$ C. moschata hybrid, L. siceraria, and Benincasa hispida rootstocks had greater firmness than nongrafted fruit [17]. Increased flesh firmness in grafted watermelon could be due to higher cell density $[55,56]$ and is a positive enhancement of fruit quality, as firm fruit have an extended shelf-life [26,57]. The impact of scion-rootstock genotypic effects on watermelon flesh firmness can be significant; therefore, choosing the right combination may be a necessary element for improving fruit quality and postharvest shelf-life $[26,46,49,58]$

\subsection{Total Soluble Solids}

Sugar and acids are the primary constituents of TSSs, in addition to small amounts of dissolved vitamins, fructans, proteins, pigments, phenolics, and minerals. TSSs are an important measure of sweetness of watermelon fruit [59]. While most research studies have generally shown that grafting has no effect on TSS content in watermelon fruit $[7,17,21,31,60,61]$ the rootstock-scion combination can affect TSSs of grafted fruit $[1,4,27]$. For example, Petropoulos et al. [62] reported variable TSSs when watermelon cvs. Sugar Baby and Crimson Sweet were grafted onto C. maxima $\times$ C. moschata hybrid rootstocks. While most studies did not find a significant effect in TSS for grafted watermelon with L. siceraria rootstocks $[33,35,36,63], 0.5-1.0 \%$ reduction in TSSs was reported for grafted compared to nongrafted watermelon treatments in several studies [26,32,35,47]. Only a few studies found grafting to have a negative impact on TSSs [64,65] and Davis and Perkins-Veazie [32] reported that TSSs were reduced only in their grafted diploid watermelon treatment.

\subsection{Fruit $p H$ and Titratable Acidity}

Unlike SSC, which shows a continuous increase during watermelon fruit growth and development, fruit $\mathrm{pH}$ was at 4.6-4.7 until about 19 days postanthesis, which increased to 5.2 just before full red color and increased to 5.4 or greater at full ripeness [66]. The $\mathrm{pH}$ of fully ripe watermelon can differ with production area, ranging from 5.4 to 6.2 , with a $\mathrm{pH}$ over 6.5 indicating overripe watermelon [67]. The $\mathrm{pH}$ of diploid watermelons grafted to an interspecific hybrid squash rootstock (cv. TZ148) was slightly lower than that of self-grafted fruit (5.7 and $5.8 \mathrm{pH}$, respectively) [24]. In a triploid watermelon (cv. Liberty), the $\mathrm{pH}$ of nongrafted or grafted fruit to an interspecific hybrid squash rootstock (cv. Carnivor) was 5.4 [45]. Titratable acidity was very low in watermelon, from $0.08-0.23 \%$ malic acid equivalents [24,68] In grafted watermelons, titratable acidity remained higher, even after ripeness, than in nongrafted fruit $[24,39]$. The slightly lower $\mathrm{pH}$ and higher titratable acidity of grafted fruit may be due to both the slight delay in fruit ripening and delayed fruit senescence, but neither had a significant effect on the marketability of fruit.

\subsection{Lycopene Content}

Watermelon is an important source of natural antioxidants due to lycopene, a fat-soluble carotenoid with valuable health-promoting benefits [69]. Lycopene content of red fleshed watermelon $(4.81 \mathrm{mg} / 100 \mathrm{~g}$ on average) is almost $40 \%$ higher than that of tomato $(3.03 \mathrm{mg} / 100 \mathrm{~g})$ [69]. Lycopene content is an important measure of watermelon fruit quality and has been reported as 
higher [24,27,47,70], lower [32,37], and unchanged [17,21,26,31,32,52,65] in grafted fruit compared with nongrafted watermelon. Grafting was reported to increase lycopene content in diploid watermelon cv. Pegasus when grafted onto interspecific hybrid squash rootstock cv. TZ148 compared to nongrafted, where optimum harvest maturity was reached between 35 and 40 days after flower initiation in the nongrafted watermelon compared to 40-45 days for the grafted watermelon [24]. Further, a decrease in lycopene content as reported with $L$. siceraria and C. argyrosperma rootstocks [32,37]. Proietti et al. [27] reported a $40 \%$ increase in lycopene content for diploid mini-watermelon cv. Ingrid when grafted onto C. maxima $\times$ C. moschata hybrid cv. PS 1313 compared to nongrafted watermelon, whereas Bruton et al. [26] found only a 5\% increase in lycopene content for triploid watermelon cv. Summer Sweet Brand 5244, grafted onto C. maxima $\times$ C. moschata cv. RS 1330 and C. ficifolia cv. RS 1420. These results demonstrate that lycopene content in grafted watermelon fruit is a rootstock-scion combination dependent trait. Differences in time to peak maturity of the cultivars in the different studies, combined with rootstocks from different genera, may influence lycopene content, possibly due to rootstock mediated regulation of lycopene metabolism [71]. Kong et al. [71] reported that L. siceraria rootstock enhanced lycopene content before the fully ripe stage in grafted watermelon by upregulating the lycopene biosynthetic genes, whereas wild watermelon (C. lanatus var. citroides) rootstock promoted lycopene accumulation in grafted watermelon fruit, potentially by downregulating lycopene catabolic genes at the fully ripe stage. Other research studies have shown that environmental conditions, such as soil fertility, irrigation, light intensity, and day/night temperatures, as well as harvest maturity and vine health, can affect lycopene formation, development, and stability in watermelon [69,72]. While numerous studies have evaluated lycopene content, the underlying mechanism of lycopene metabolism is still unclear in grafted watermelon fruit.

\subsection{Citrulline}

Although not present in most foods, the non-essential amino acid L-citrulline is found in high amounts in watermelon. Consumption of watermelon juice containing 4-6 g citrulline + arginine was found to effectively lower blood pressure and arterial stiffness [73,74]. The effects of grafting rootstock on subsequent fruit citrulline content was mixed. Soteriou et al. [23] reported higher amounts in grafted watermelon fruit (2.5 vs 3.0), although no significant differences in L-citrulline were found in 'Liberty' (2.7-3.1 in 2017 and 3.4 in 2019) [45]. The different results may be from different rootstock genetics and relative amounts of root-available potassium. Zhong et al. [75] found that nongrafted watermelon fruit were lower in citrulline than those grafted to wild watermelon, bottle gourd, or interspecific hybrid rootstocks when hydroponic solutions of 0.1 - and 6-mM potassium were applied. The amount of citrulline increased at low levels of applied potassium, except for fruit grafted to the interspecific rootstock. Amounts of potassium found in the fruit tissue corresponded to application rates and were similar among grafted plants but were reduced for the low potassium application rate in nongrafted plants [76].

\section{Conclusions}

Research studies demonstrate that grafting can effectively mitigate the adverse effects of environmental stress on watermelon production. Abiotic stress tolerance of grafted plants is facilitated by the modifications in root traits, such as deeper and more extensive root systems, higher root hydraulic conductance, and faster induction of hormone accumulation (for example, abscisic acid). Rootstock/scion combinations can influence stress tolerance of grafted plants under different environmental conditions. Hormonal signaling plays an important role in graft union formation, rootstock-scion communication, growth and yield, and potential flowering and fruit quality. Fruit quality measures can be confounded by non-standardization of harvest maturity of grafted and nongrafted plants, and there is need for further research regarding timing of maturation to optimize fruit quality of grafted watermelon. Although the changes in fruit quality after grafting have been widely reported, the mechanisms involved in regulating fruit characteristics with different rootstocks are still 
unknown. Future research needs to focus on rootstock performance within specific growing regions, soil type, and weather conditions to enhance fruit quality and extend shelf-life. In addition, there is a need to evaluate multiple scion and rootstock combinations to better understand the interaction effects on fruit quality under varying environmental conditions. To fully understand the impact of grafting on fruit yield and quality, studies need to provide cultivar information and climate data. Furthermore, research efforts are needed to understand the diverse roles of post-grafting biological and metabolic processes at the molecular level and should take watermelon rootstock selection into consideration. Formation of hollow heart and hard seeds also need special attention in grafted triploid watermelon, as there is limited research that has addressed these two fruit quality issues. This information will enable growers to select scion and rootstock cultivars for consistency of performance across locations. Perhaps most importantly, there is a need to determine the impact of grafting on fruit development and ripening in order to recommend maturity indicators and timing for harvest to optimize fruit quality of grafted watermelon. Finally, researchers, agriculture extension specialists, and industry professionals need to work together to disseminate this information in order for growers to view grafting as an effective tool for producing high-quality watermelon under unfavorable environmental conditions.

Author Contributions: Conceptualization, C.M. and P.D.; writing-original draft preparation, P.D.; writing-review and editing, C.M., P.D., and P.P.-V. All authors have read and agreed to the published version of the manuscript.

Funding: Funding support was provided by the U.S. Department of Agriculture National Institute of Food and Agriculture (NIFA) Specialty Crop Research Initiative Grant 2016-51181-25404 and NIFA Hatch project 1017286.

Acknowledgments: We appreciate internal review by Lisa De Vetter, and technical support by Ed Scheenstra and Patti Kreider.

Conflicts of Interest: The authors declare no conflict of interest.

\section{References}

1. Davis, A.R.; Perkins-Veazie, P.; Sakata, Y.; Galarza, S.L.Ó.; Maroto, J.V.; Lee, S.G.; Huh, Y.C.; Miguel, A.; King, S.R.; Cohen, R.; et al. Cucurbit grafting. Crit. Rev. Plant Sci. 2008, 27, 50-74. [CrossRef]

2. Lee, J.M.; Kubota, C.; Tsao, S.J.; Bie, Z.; Echevarria, P.H.; Morra, L.; Oda, M. Current status of vegetable grafting: Diffusion, grafting techniques, automation. Sci. Hortic. 2010, 127, 93-105. [CrossRef]

3. Colla, G.; Rouphael, Y.; Leonardi, C.; Bie, Z. Role of grafting in vegetable crops grown under saline conditions. Sci. Hortic. 2010, 127, 147-155. [CrossRef]

4. Flores, F.B.; Sanchez-Bel, P.; Estan, M.T.; Martinez-Rodriguez, M.M.; Moyano, E.; Morales, B.; Bolarín, M.C. The effectiveness of grafting to improve tomato fruit quality. Sci. Hortic. 2010, 125, 211-217. [CrossRef]

5. Kumar, P.; Lucini, L.; Rouphael, Y.; Cardarelli, M.; Kalunke, R.M.; Colla, G. Insight into the role of grafting and arbuscular mycorrhiza on cadmium stress tolerance in tomato. Front. Plant Sci. 2015, 6, 477. [CrossRef] [PubMed]

6. Rouphael, Y.; Rea, E.; Cardarelli, M.; Bitterlich, M.; Schwarz, D.; Colla, G. Can adverse effects of acidity and aluminum toxicity be alleviated by appropriate rootstock selection in cucumber? Front. Plant Sci. 2016, 7, 1283. [CrossRef] [PubMed]

7. Miguel, A.; Maroto, J.V.; Bautista, A.S.; Baixauli, C.; Cebolla, V.; Pascual, B.; Lopez, S.; Guardiola, J.L. The grafting of triploid watermelon is an advantageous alternative to soil fumigation by methyl bromide for control of Fusarium wilt. Sci. Hortic. 2004, 103, 9-17. [CrossRef]

8. Cohen, R.; Dombrovsky, A.; Louws, F.J. Grafting as agrotechnology for reducing disease damage. In Vegetable Grafting: Principles and Practices; Colla, G., Pérez-Alfocea, F., Schwarz, D., Eds.; CAB International: Oxford, UK, 2017; pp. 155-170. [CrossRef]

9. Kumar, P.; Rouphael, Y.; Cardarelli, M.; Colla, G. Vegetable grafting as a tool to improve drought resistance and water use efficiency. Front. Plant Sci. 2017, 8, 1130. [CrossRef]

10. Louws, FJ.; Rivard, C.L.; Kubota, C. Grafting fruiting vegetables to manage soilborne pathogens, foliar pathogens, arthropods and weeds. Sci. Hortic. 2010, 127, 127-146. [CrossRef]

11. Nawaz, M.A.; Imtiaz, M.; Kong, Q.; Cheng, F.; Ahmed, W.; Huang, Y.; Bie, Z. Grafting: A technique to modify ion accumulation in horticultural crops. Front. Plant Sci. 2016, 7, 1457. [CrossRef] 
12. Aloni, B.; Cohen, R.; Karni, L.; Aktas, H.; Edelstein, M. Hormonal signaling in rootstock-scion interactions. Sci. Hortic. 2010, 127, 119-126. [CrossRef]

13. Pulgar, G.; Villora, G.; Moreno, D.A.; Romero, L. Improving the mineral nutrition in grafted watermelon plants: Nitrogen metabolism. Biol. Plant. 2000, 43, 607-609. [CrossRef]

14. Sakata, Y.; Ohara, T.; Sugiyama, M. The history and present state of the grafting of cucurbitaceous vegetables in Japan. Acta Hort. 2007, 731, 159-170. [CrossRef]

15. Satoh, S. Inhibition of flowering of cucumber grafted on rooted squash stocks. Physiol. Plant. 1996, 97, 440-444. [CrossRef]

16. Yamasaki, A.; Yamashita, M.; Furuya, S. Mineral concentrations and cytokinin activity in the xylem exudate of grafted watermelons as affected by rootstocks and crop load. J. Jpn. Soc. Hortic. Sci. 1994, 62, 817-826. [CrossRef]

17. Devi, P.; Perkins-Veazie, P.; Miles, C.A. Rootstock and plastic mulch effect on watermelon flowering and fruit maturity in a Verticillium dahliae infested field. HortScience 2020, 55, 1438-1445. [CrossRef]

18. Kyriacou, M.C.; Rouphael, Y.; Colla, G.; Zrenner, R.; Schwarz, D. Vegetable grafting: The implications of a growing agronomic imperative for vegetable fruit quality and nutritive value. Front. Plant Sci. 2017, 8, 741. [CrossRef]

19. Kader, A.A. Flavor quality of fruits and vegetables. Perspective. J. Sci. Food Agric. 2008, 88, 1863-1868. [CrossRef]

20. Kroggel, M.; Kubota, C. 2017 Potential Yield Increase by Grafting for Watermelon Production in Arizona; College of Agriculture, University of Arizona: Tucson, AZ, USA, 2017. Available online: https://repository.arizona.edu/ bitstream/handle/10150/625432/az1732-2017_0.pdf?sequence=1\&isAllowed=y (accessed on 20 April 2019).

21. Devi, P.; Lukas, S.; Miles, C. Fruit maturity and quality of splice-grafted and one-cotyledon grafted watermelon. HortScience 2020, 55, 1090-1098. [CrossRef]

22. Lee, J.M. Cultivation of grafted vegetables i. current status, grafting methods, and benefits. HortScience 1994, 29, 235-239. [CrossRef]

23. Masuda, M.; Gomi, K. Mineral absorption and oxygen consumption in grafted and non-grafted cucumbers. J. Jpn. Soc. Hortic. Sci. 1984, 52, 414-419. [CrossRef]

24. Soteriou, G.A.; Kyriacou, M.C.; Siomos, A.S.; Gerasopoulos, D. Evolution of watermelon fruit physicochemical and phytochemical composition during ripening as affected by grafting. Food Chem. 2014, 165, 282-289. [CrossRef] [PubMed]

25. U.S. Department of Agriculture. United States Standards for Grades of Watermelons; Agricultural Marketing Service, U.S. Department of Agriculture: Washington, DC, USA, 2006. Available online: https://www.ams. usda.gov/sites/default/files/media/Watermelon_Standard\%5B1\%5D.pdf (accessed on 3 April 2019).

26. Bruton, B.D.; Fish, W.W.; Roberts, W.; Popham, T.W. The influence of rootstock selection on fruit quality attributes of watermelon. Open Food Sci. J. 2009, 3, 15-34. [CrossRef]

27. Proietti, S.; Rouphael, Y.; Colla, G.; Cardarelli, M.; de Agazio, M.; Zacchini, M.; Rea, E.; Moscatello, S.; Battistelli, A. Fruit quality of mini-watermelon as affected by grafting and irrigation regimens. J. Sci. Food Agric. 2008, 88, 1107-1114. [CrossRef]

28. Wang, Q.; Men, L.; Gao, L.; Tian, Y. Effect of grafting and gypsum application on cucumber (Cucumis sativus L.) growth under saline water irrigation. Agric. Water Manag. 2017, 188, 79-90. [CrossRef]

29. Kakizaki, T.; Kitashiba, H.; Zou, Z.; Li, F.; Fukino, N.; Ohara, T.; Nishio, T.; Ishida, M. A 2-oxoglutarate-dependent dioxygenase mediates the biosynthesis of glucoraphasatin in radish. Plant Physiol. 2017, 173, 1583-1593. [CrossRef] [PubMed]

30. Cohen, R.; Burger, Y.; Horev, C. Introducing grafted cucurbits to modern agriculture: The Israeli experience. Plant Dis. 2007, 91, 916-923. [CrossRef]

31. Dabirian, S.; Inglis, D.; Miles, C. Grafting watermelon and using plastic mulch to control verticillium wilt caused by Verticillium dahliae in Washington. HortScience 2017, 52, 349-356. [CrossRef]

32. Davis, R.A.; Perkins-Veazie, P. Rootstock effects on plant vigor and watermelon fruit quality. Cucurbit Genet. Coop. Rpt. 2005, 28-29, 39-41. Available online: https://www.researchgate.net/publication/285707492 Rootstock_effects_on_plant_vigor_and_watermelon_fruit_quality (accessed on 15 July 2019).

33. Wimer, J.A.; Miles, C.A.; Inglis, D.A. Evaluating grafted watermelon for verticillium wilt severity, yield, and fruit quality in Washington State. HortScience 2015, 50, 1332-1337. [CrossRef] 
34. Alexopoulos, A.A.; Kondylis, A.; Passam, H.C. Fruit yield and quality of watermelon in relation to grafting. J. Food Agric. Environ. 2007, 5, 178-179.

35. Rouphael, Y.; Schwarz, D.; Krumbein, A.; Colla, G. Impact of grafting on product quality of fruit vegetables. Sci. Hortic. 2010, 127, 172-179. [CrossRef]

36. Alan, O.; Zdemir, N.; Nen, Y. Effect of grafting on watermelon plant growth, yield and quality. J. Agron. 2007, 6, 362-365. [CrossRef]

37. Candir, E.; Yetişir, H.; Karaca, F.; Ustun, D. Phytochemical characteristics of grafted watermelon on different bottle gourds (Lagenaria siceraria) collected from the Mediterranean region of Turkey. Turk. J. Agric. 2013, 37, 443-456. [CrossRef]

38. Huitrón, M.V.; Ricárdez, M.; Dianez, F.; Camacho, F. Influence of grafted watermelon plant density on yield and quality in soil infested with melon necrotic spot virus. HortScience 2009, 44, 1838-1841. [CrossRef]

39. Kyriacou, M.C.; Soteriou, G.A.; Rouphael, Y.; Siomos, A.S.; Gerasopoulos, D. Configuration of watermelon fruit quality in response to rootstock-mediated harvest maturity and postharvest storage. J. Sci. Food Agric. 2016, 96, 2400-2409. [CrossRef]

40. Johnson, G. 2014 These Beautiful Watermelon Patterns are Driving Everyone Crazy. Available online: https://www.boredpanda.com/weird-watermelons-beautiful-hollow-heart/ (accessed on 22 August 2018).

41. Trandel, M.A.; Perkins-Veazie, P.; Schultheis, J.; Gunter, C.; Johannes, E. Grafting watermelon onto interspecific hybrid squash reduces hollow heart disorder. In II International Symposium on Vegetable Grafting; ISHS: Charlotte, NC, USA, 2019. Available online: https:/www.researchgate.net/publication/336880681_Grafting watermelon_to_interspecific_hybrid_rootstock_reduces_hollow_heart_disorder (accessed on 2 March 2018).

42. Kano, Y. Relationship between the occurrence of hollowing in watermelon and the size and the number of fruit cells and intercellular air spaces. J. Jpn. Soc. Hortic. Sci. 1993, 62, 103-112. [CrossRef]

43. Johnson, G. 2015 Research Finds Potential Cause of Hollow Heart Disorder in Watermelon. Available online: https://phys.org/news/2015-06-potential-hollow-heart-disorder-watermelons.html (accessed on 22 August 2018).

44. Maynard, D.N. 1992 Growing Seedless Watermelon Univ. FL. Coop. Ext. Serv. Fact Sheet HS687. Available online: http://edis.ifas.ufl.edu/CV006 (accessed on 2 December 2019).

45. Trandel, M.A. Cell Wall Polysaccharides in Grafted and Non-Grafted 'Liberty' Watermelon with Hollow Heart. Ph.D. Thesis, North Carolina State University, Raleigh, NC, USA, 2020. Available online: https: //www.lib.ncsu.edu/resolver/1840.20/38167 (accessed on 12 September 2020).

46. Hodge, L. Growing Seedless (Triploid) Watermelon; Neb Guide; University of Nebraska-Lincoln Ext.: Lincoln, NE, USA, 1994; Available online: https://extensionpublications.unl.edu/assets/pdf/g1755.pdf (accessed on 20 April 2019).

47. Kyriacou, M.; Soteriou, G. Quality and postharvest performance of watermelon fruit in response to grafting on interspecific cucurbit rootstocks. J. Food Qual. 2015, 38, 21-29. [CrossRef]

48. Paroussi, G.; Bletsos, F.; Bardas, G.A.; Kouvelos, J.A.; Klonari, A. Control of fusarium and verticillium wilt of watermelon by grafting and its effect on fruit yield and quality. Proc. IIIrd Balkan Symp. Veg. and Potatoes. Acta Hortic. (ISHS) 2007, 729, 281-285. [CrossRef]

49. Yetisir, H.; Sari, N.; Y"ucel, S. Rootstock resistance to fusarium wilt and effect on watermelon fruit yield and quality. Phytoparasitica 2003, 31, 163-169. [CrossRef]

50. Alan, O.; Sen, F.; Duzyaman, E. The effectiveness of growth cycles on improving fruit quality for grafted watermelon combinations. Food Sci. Technol. 2018, 38, 270-277. [CrossRef]

51. Buller, S.; Inglis, D.; Miles, C. Plant growth, fruit yield and quality, and tolerance to verticillium wilt of grafted watermelon and tomato in field production in the Pacific Northwest. HortScience 2013, 48, 1-7. [CrossRef]

52. Karaca, F.; Yetişir, H.; Solmaz, I.; Çandır, E.; Kurt, S.; Sari, N.; Guler, Z. Rootstock potential of Turkish Lagenaria siceraria germplasm for watermelon: Plant growth, yield and quality. Turk. J. Agric. For. 2012, 36, 167-177. Available online: https://journals.tubitak.gov.tr/agriculture/issues/tar-12-36-2/tar-36-2-4-1101-1716. pdf (accessed on 20 July 2018).

53. Soteriou, G.A.; Kyriacou, M.C. Rootstock-mediated effects on watermelon field performance and fruit quality characteristics. Int. J. Veg. Sci. 2015, 21, 344-362. [CrossRef]

54. Liu, R.Q.; Zhang, H.M.; Xu, J.H. Effects of rootstocks on growth and fruit quality of grafted watermelon. J. Shanghai Jiaotong Univ. Agric. Sci. 2003, 21, 289-294. 
55. Fallik, E.; Ziv, C. How rootstock/scion combinations affect watermelon fruit quality after harvest? J. Sci. Food Agric. 2020. [CrossRef]

56. Soteriou, G.A.; Siomos, A.S.; Gerasopoulos, D.; Rouphael, Y.; Georhiadou, S.; Kyriacou, M.C. Biochemical and histological contrition to texture changes in watermelon fruit modulated by grafting. Food Chem. 2017, 237, 133-140. [CrossRef]

57. Saftner, R.; Abbott, J.A.; Lester, G.; Vinyard, B. Sensory and analytical comparison of orange-fleshed honeydew to cantaloupe and green-fleshed honeydew for fresh-cut chunks. Postharvest Biol. Technol. 2006, 42, 150-160. [CrossRef]

58. Cushman, E.K.; Huan, J. Performance of four triploid watermelon cultivars grafted onto five rootstock genotypes: Yield and fruit quality under commercial growing conditions. Acta Hortic. 2008, 782, 335-342. [CrossRef]

59. Magwaza, L.S.; Opara, U.L. Analytical methods for determination of sugars and sweetness of horticultural products-A review. Sci. Hortic. 2015, 184, 179-192. [CrossRef]

60. Colla, G.; Rouphael, Y.; Cardarelli, M.; Massa, D.; Salerno, A.; Rea, E. Yield, fruit quality and mineral composition of grafted melon plants grown under saline conditions. J. Hortic. Sci. Biotechnol. 2006, 81, 146-152. [CrossRef]

61. Chouka, A.; Jebari, H. Effect of grafting on watermelon vegetative and root development, production and fruit quality. Acta Hortic. 1999, 492, 85-94. [CrossRef]

62. Petropoulos, S.A.; Khah, E.M.; Passam, H.C. Evaluation of rootstocks for watermelon grafting with reference to plant development, yield and fruit quality. Int. J. Plant Prod. 2012, 6, 481-492. [CrossRef]

63. Yetisir, H.; Sari, N. Effect of different rootstock on plant growth, yield and quality of watermelon. Austral. J. Expt. Agric. 2003, 43, 1269-1274. [CrossRef]

64. López-Galarza, S.; Batista, A.S.; Perez, D.M.; Miquel, A.; Baixauli, C.; Pascual, B.; Maroto, J.V.; Guardiola, J.L. Effects of grafting and cytokinin-induced fruit setting on colour and sugar-content traits in glasshouse-grown triploid watermelon. J. Hortic. Sci. Biotechnol. 2004, 79, 971-976. [CrossRef]

65. Turhan, A.; Ozman, N.; Kuscu, H.; Serbeci, M.S.; Seniz, V. Influence of rootstocks on yield and fruit characteristics and quality of watermelon. Hortic. Environ. Biotechnol. 2012, 53, 336-341. [CrossRef]

66. Corey, A.K.; Schlimme, D.V. Relationship of rind gloss and groundspot color to flesh quality of watermelon fruits during maturation. Sci. Hortic. 1988, 211-218. [CrossRef]

67. Perkins-Veazie, P.; Collins, J.K.; Davis, A.R.; Roberts, W. Carotenoid content of 50 watermelon cultivars. J. Agric. Food Chem. 2006, 54, 2593-2597. [CrossRef]

68. Mao, L.; Jeong, J.; Que, F.; Huber, D.J. Physiological properties of fresh-cut watermelon (Citrullus lanatus) in response to 1-methylcyclopropene and post-processing calcium application. J. Sci. Food. Agric. 2006, 86, 46-53. [CrossRef]

69. Naz, A.; Butt, M.S.; Sultan, M.T.; Qayyum, M.M.; Niaz, R.S. Watermelon lycopene and allied health claims. EXCLI J. 2014, 13, 650-660. [CrossRef]

70. Perkins-Veazie, P.; Collins, J.K. Carotenoid changes of intact watermelon after storage. J. Agric. Food Chem. 2006, 54, 5868-5874. [CrossRef] [PubMed]

71. Kong, Q.; Yuan, J.; Gao, L.; Liu, P.; Cao, L.; Huang, Y.; Zhao, L.; Lv, H.; Bie, Z. Transcriptional regulation of lycopene metabolism mediated by rootstock during the ripening of grafted watermelons. Food Chem. 2017, 214, 406-411. [CrossRef] [PubMed]

72. Perkins-Veazie, P.; Collins, J.K.; Pair, S.D.; Roberts, W. Lycopene content differs among red-fleshed watermelon cultivars. J. Sci. Food Agric. 2001, 81, 983-987. [CrossRef]

73. Figueroa, A.; Sanchez-Gonzalez, M.A.; Perkins-Veazie, P.M.; Arjmandi, B.H. Effects of watermelon supplementation on aortic blood pressure and wave reflection in individuals with prehypertension: A pilot study. Am. J. Hypertens. 2011, 24, 40-44. [CrossRef]

74. Figueroa, A.; Sanchez-Gonzalez, M.A.; Wong, A.; Arjmandi, B.H. Watermelon extract supplementation reduces ankle blood pressure and carotid augmentation index in obese adults with prehypertension or hypertension. Am. J. Hypertens. 2012, 25, 640-643. [CrossRef]

75. Zhong, Y.; Shi, J.; Zheng, Z.; Nawaz, M.A.; Chen, C.; Cheng, F.; Kong, Q.; Bie, Z.; Huang, Y. NMR-based fruit metabonomic analysis of watermelon grafted onto different rootstocks under two potassium levels. Sci. Hortic. 2019, 258, 108793. [CrossRef] 
76. Zhong, Y.; Chen, C.; Nawaz, M.A.; Jiao, Y.; Zheng, Z.; Shi, X.; Xie, W.; Yu, Y.; Guo, J.; Zhu, S.; et al. Using rootstock to increase watermelon fruit yield and quality at low potassium supply: A comprehensive analysis from agronomic, physiological and transcriptional perspective. Sci. Hortic. 2018, 241, 144-151. [CrossRef]

Publisher's Note: MDPI stays neutral with regard to jurisdictional claims in published maps and institutional affiliations.

(C) 2020 by the authors. Licensee MDPI, Basel, Switzerland. This article is an open access article distributed under the terms and conditions of the Creative Commons Attribution (CC BY) license (http://creativecommons.org/licenses/by/4.0/). 